IRSH 54 (2009), pp. 359-389 doi:I0.1017/So020859009990307

(C) 2009 Internationaal Instituut voor Sociale Geschiedenis

\title{
The Legal Status of Labour from the Seventeenth to the Nineteenth Century: Russia in a Comparative European Perspective*
}

\author{
A LESSANDRO STANZIANI \\ EHESS, Paris \\ CNRS (IDHE), Paris
}

E-mail: alessandro.stanziani@idhe.ens-cachan.fr

Summary: Since at least the eighteenth century, free labour in "the West" has been contrasted with serf labour in Russia and "eastern Europe". This paper intends to call that view into question and to show that serfdom was never officially institutionalized in Russia, and that the regulations usually invoked to justify that opinion were actually intended not to "bind" the peasantry but to identify noble estate owners, as distinct from nobles in state service or the "bourgeoisie". However, it is a matter not only of legal definitions. This paper studies how the tsarist administration, nobles, and peasants themselves made use of courts of law in order to contest ownership titles and, on that basis, the obligations and legal status of peasants and workers. Great changes had occurred in their legal status before the official abolition of serfdom in I86I, in outcomes that were rather similar to those which had been recently achieved in the "second serfdom" in Prussia, Lithuania, and Poland. In turn, that means that such labour contracts and institutions were not the opposites of "free labour" contracts and institutions, which placed many more constraints on workers than is usually acknowledged. To prove the point, we compare tsarist regulations with the Master and Servants Acts and indenture in Britain and its Empire and with French regulations on labour, domesticity, and day labourers.

\section{INTRODUCTION}

Since the eighteenth century at least, comparatives analyses of labour institutions and labour conditions in Russia have been made as if the boundary between free and unfree labour were ahistorically and universally defined.

\footnotetext{
* I should like to thank my colleagues David Moon (University of Durham), Elise Kimerling Wirtschafter (California State Polytechnic University, Pomona, CA), and Kenneth Pomeranz (University of California, Irvine, CA), and two anonymous referees for their valuable suggestions. I should like also to record my special thanks to the editorial board of the IRSH for their help and valuable comments.
} 
Free labour in "the West" is thus contrasted with serf labour in Russia and "eastern Europe". We intend to call that view into question and to show that serfdom was never officially institutionalized in Russia, and that the rules usually invoked to justify that opinion were actually intended not to "bind" the peasantry but to identify noble estate owners, as distinct from nobles in state service or the "bourgeoisie".

However, it is a matter not only of legal definitions. We shall study the ways in which the tsarist administration, nobles, and peasants themselves made use of courts of law in order to contest ownership titles and, on that basis, the obligations and legal status of peasants and workers. Great changes had occurred in their legal status before the official abolition of serfdom in I86I, in outcomes that were rather similar to those which had been recently achieved in the "second serfdom" in Prussia, Lithuania, and Poland. ${ }^{\mathrm{I}}$ In turn, that means that such labour contracts and institutions were not the opposites of so-called "free labour" contracts and institutions, which placed many more constraints on workers than is usually acknowledged.

To prove the point, since the link between the Master and Servants Acts and indenture has already been explored, ${ }^{2}$ we shall pay particular attention to the presumed "French exception". France is still considered the only country in the West to have abolished service, as synonymous with wage labour, and punishment for breach of contract as a crime at the end of the eighteenth century - Britain, the United States, and Germany followed a century later. We intend to put that assertion to the test, focusing on French engagés (indentured workers) and rural labourers, both of which categories were subject to heavy legal constraints during the nineteenth century.

Our work is based on both archive and published sources. We have made use of Russian archives, mostly archives of ancient Russia (RGADA) and local archives in Moscow (TsGIAM), including decisions of local courts of law. To those must be added the impressive collection of Russian laws, decrees, and case law, ${ }^{3}$ which gives us the opportunity to capture the almost incredible number of rules concerning our subject, their connection with rules governing the nobility and family, and the main legal decisions adopted by the high courts and the senate in Russia.

I. Edgar Melton, "Population Structure, the Market Economy, and the Transformation of Gutsherrschaft in East Central Europe, 1650-1800: The Cases of Brandenburg and Bohemia", German History, 16 (1998), pp. 297-327; William Hagen, Ordinary Prussians: Brandenburg Junkers and Villagers, I500-I840 (Cambridge, 2002).

2. Robert Steinfeld, The Invention of Free Labor: The Employment Relation in English and American Law and Culture (Chapel Hill, NC, 1991).

3. Polnoe sobranie zakonov Rossiiskoi Imperii [Full Collection of Laws of the Russian Empire], henceforth PSZ, three series: I: I649-I 825 , 46 vols (St Petersburg, I 830); II: I825-I88 I, 55 vols (St Petersburg, I830-I884); III: I88 I-I9I3, 33 vols (St Petersburg, I885-I9I6). 
French archives, both national and local, and French case law, as well as British and American legal judgments on questions about labour, servants, and the colonies, have been explored equally fully. Further, we have made extensive use of published Russian, French, and English sources from the eighteenth and nineteenth centuries and of the huge bibliography on this topic available in all those countries.

\section{RULES OF SERFDOM}

The historiography of Russian serfdom has focused mainly on its origin (in the state, ${ }^{4}$ or landowners), and its profitability, ${ }^{5}$ rather than on the interplay between its legal rules and economic activity. The most remarkable contributions are those of Hoch, Wirtschafter, Melton, and Moon, who have effectively revisited the simplistic definition and functioning of Russian "serfdom". ${ }^{6}$ Serfdom's dynamics and rules have been

4. J. Blum, Lord and Peasant in Russia: From the Ninth to the Nineteenth Century (New York, 1964); A. Gershenkron, Economic Backwardness in Historical Perspective (Cambridge, MA, 1962); Olga Crisp, Studies in the Russian Economy before 1914 (London, 1976); R. Portal, "The Industrialization of Russia", in H. Habakkuk and M. Postan (eds), The Cambridge Economic History of Europe from the Decline of the Roman Empire, VI, Part 2: The Industrial Revolutions and After: Incomes, Population and Technological Change (Cambridge, 1965), p. 51; A. Kahan, "Capital Formation During the Period of Early Industrialization in Russia, I890-I9I3", in P. Mathias and M. Postan (eds), The Cambridge Economic History of Europe from the Decline of the Roman Empire, VII, Part 2: The Industrial Economies: Capital, Labour, and Enterprise (Cambridge, I978), pp. 265-275; R. Bartlett, "Serfdom and State Power in Imperial Russia", European History Quarterly, 33 (2003), pp. 29-64; Richard Hellie, Enserfment and Military Change in Muscovy (Chicago, IL, 1971); P. Kolchin, Unfree Labor: American Slavery and Russian Serfdom (Cambridge, I987); M.L. Bush (ed.), Serfdom and Slavery: Studies in Legal Bondage (Manchester, 1996); and Daniel Field, The End of Serfdom: Nobility and Bureaucracy in Russia, I855-I86I (Cambridge, MA, 1976).

5. P. Struve, Krepostnoe khoziaistvo. Issledovaniia po ekonomicheskoi istorii Rossii v XVIII $i$ $X I X v v$ [The Serf Economy: Studies on the Economic History of Russia, Eighteenth to the Nineteenth Century] (St Petersburg, I913); I.D. Koval'chenko, Russkoe krepostnoe krest'ianstvo v pervoi polovine XIXth v. [The Russian Serf Peasantry during the First Half of the Nineteenth Century] (Moscow, 1967); Ian Blanchard, Russia's Age of Silver: Precious Metal Production and Economic Growth in the Eighteenth Century (New York, I989); David Moon, The Abolition of Serfdom in Russia, I762-1907 (London, 200I); T.K. Dennison, "Did Serfdom Matter? Russian Rural Society, 1750-1860", Historical Research, 79:203 (2003), pp. 74-89; Edgar Melton, "Proto-Industrialization, Serf Agriculture and Agrarian Social Structure: Two Estates in Nineteenth-Century Russia", Past E Present, IIs (1987), pp. 73-8I; idem, "Enlightened Seignorialism and its Dilemmas in Serf Russia, I750-1830", Journal of Modern History, 62 (1990), pp. 675-708; and Steven Hoch, Serfdom and Social Control in Russia: Petrovskoe, A Village in Tambov (Chicago, IL, 1986). See too E. Domar and M. Machina, "On the Profitability of Russian Serfdom", The Journal of Economic History, 44 (1984), pp. 919-955. 6. Hoch, Serfdom and Social Control in Russia; Melton, "Enlightened Seignorialism and its Dilemmas", and idem, "Proto-Industrialization, Serf Agriculture and Agrarian Social Structure”; Elise Kimerling Wirtschafter, Structures of Society: Imperial Russia's "People of Various 
questioned; it has been suggested that serfdom was never officially introduced ${ }^{7}$ and that it was much more a set of practices than a true system. ${ }^{8}$ We are keen to extend research in the same direction by analysing the rules defining the legal status of actors and assessing their implementation.

We shall show that the rules never spoke of "serfs" but rather aimed to identify people entitled to transmit "immovable" property. In fact, Russian and Western historiography from the twentieth century to today considers krepostnoe pravo as the equivalent in the Russian language of the word "serfdom", just as krepostnye liudi has been translated as "serfs". That translation might be correct, but one problem is that the expression krepostnoe pravo did not appear in Russian texts until the years preceding the reforms of i 86I. If we consider official Russian texts from the sixteenth to the middle of the nineteenth century, we find no krepostnoe pravo nor krepostnye lindi (people subject to a krepost', a deed) but only krest'iane (peasants) and the rural population.

The limitation of the mobility of peasants has to be viewed in that context, for although not a goal in itself, such limitation did affect relationships between different groups of landowners and the state. ${ }^{9}$ The Muscovite state did precisely that in I 550, when the Sudebnik (law reports) incorporated and widely applied the provisions originally intended (I455-I462) only for monastery peasants, which consisted in limiting their mobility. ${ }^{10}$ The rules were thus appropriated by the state and broadened to include the entire peasantry in relation to a particular operation, namely the attempt by Muscovite leaders to establish a land register.

Throughout the sixteenth and seventeenth centuries, several rules were adopted which had the effect of limiting peasant mobility; however, those rules actually aimed to establish a cadastre in order to improve tax income and military conscription, but also to settle arguments over estates to

Ranks" (DeKalb, IL, I994); Elise Kimerling Wirtschafter, Social Identity in Imperial Russia (DeKalb, IL, I997); Moon, Abolition of Serfdom; idem, "Reassessing Russian Serfdom", European History Quarterly, 26 (1996), pp. 483-526; idem, The Russian Peasantry, I600-1930: The World the Peasants Made (London, 1996).

7. Bartlett, "Serfdom and State Power in Imperial Russia"; Wirtschafter, Structures of Society, and idem, Social Identity in Imperial Russia.

8. Examples of this can be found in Hoch, Serfdom and Social Control in Russia, and Dennison, "Did Serfdom Matter?".

9. Cadastre documents (Pistsovye knigi) are largely available in RGADA in a large number of collections, including f. I 239, op. 3, ch. I7, 69-72, 74, 76, 86-87 (cadastres of Moscow district, I674-I68I); f. 396, op. 2, ch. 5 (I616-I732), Smolensk, and several other districts; fonds I 209 (prilozhenie arkhiv prezhnikh votchinnykh del, I565-I692), op. I, ch. I-3, op. 2, ch. I-2, op. 16-72.

I0. Daniel Kaiser, The Growth of the Law in Medieval Russia (Princeton, NJ, I980), provides a detailed analysis of the different editions of the Sudebnik (I550, I589, and I606). 
which there were various claimants, including different categories of noble, the crown, the Church, and monasteries. In other words, among the Muscovite elites claims to land and conflicts over them were at the root of rules concerning the cadastre and, only implicitly, peasant mobility. ${ }^{\text {II }}$ The provisions meant that peasants could move from central "black earth" lands to state or court lands, if they felt so inclined, and there is no doubt that many peasants moved freely about Russia and that the government took measures to ensure they had the right to do so. Until the first half of the seventeenth century, it was assumed that the restriction was temporary; by the 1630 landlords even came to enjoy the right to allow their peasants to move, as expressed in a document they signed (the otpusknaia gramota). ${ }^{\mathrm{I2}}$

These measures were dictated not only by the taxation and military requirements of the state, ${ }^{\mathrm{I} 3}$ which were linked to Russian territorial expansion, ${ }^{14}$ but overlapped with a significant redefinition of the relationships between social groups and that state, especially the value of land ownership as a social and political marker. ${ }^{15}$ The Russian elites welcomed the requests of the provincial nobility to legitimize their properties, for the elites could thereby secure an important ally in their fight against the boiare. The delimitation of properties and the increasingly strong link between land ownership and the obligations of the resident population formed the point at which the interests of the state and those of small landowners intersected. The process was by no means simple, however, as is evidenced by the numerous legal disputes and petitions drawn up by noble families against other claimants to their properties, whether other nobles, merchants, boiare, or others. ${ }^{16}$ The position was complicated even more by the fact that landowners were ready to keep runaway peasants and that the state was unable to enforce the relevant rules. In other words, limitations to peasant mobility were part of a wider game being played by opposing Russian elites.

i I. Henry Eaton, "Cadasters and Censuses of Muscovy", Slavic Revierw, 26 (1967), pp. 54-69; the most complete list of published sixteenth and seventeenth cadastral records is in S.V. Voznesenskii, Materialy dlia bibliografii po istorii narodov SSSR XVI-XVIIvv [Materials for a Bibliography on the History of the People of the USSR, Sixteenth to the Seventeenth Century] (Leningrad, I933).

I2. Hellie, Enserfment and Military Change in Muscovy, p. 108.

I3. W.C. Fuller, Strategy and Power in Russia, I600-1914 (New York, I992); and Carol S. Leonard, Reform and Regicide: The Reign of Peter III of Russia (Bloomington, IN, 1993).

I4. Moon, Abolition of Serfdom; Blum, Lord and Peasant in Russia, Dennison, "Did Serfdom Matter?"; Hellie, Enserfment and Military Change in Muscovy, and idem, Slavery in Russia: 1450-1725 (Chicago, IL, I982); P. Perdue, "Military Mobilization in Seventeenth and Eighteenth-Century China, Russia, and Mongolia", Modern Asian Studies, 30 (1996), pp. 757-793. I 5. Moon, "Reassessing Russian Serfdom"; P.A. Zaionchkovskii, Otmena krepostnogo prava v Rossii [The Abolition of Serfdom in Russia], 3rd edn (Moscow, I968).

I6. R. Crummey, "Sources of Boyar Power in the Seventeenth Century", Cabiers du Monde Russe, 34:I-2 (1993), pp. 107-I I 8. 
The alliance between the state and the provincial and lesser nobility was supposed to offer a solution, new rules on runaways being adopted in exchange for landowners' acceptance of a cadastre. However, that agreement proved to be ineffective as different state administrations were unable to cooperate in achieving a cadastre, returning runaways, and punishing owners whose claims were illegitimate. To that must be added the lack of cooperation among landowners, who continued to retain peasants who were on the move - "runaways". This is where the famous Ulozhenie of I 649 comes in; according to many interpretations, Russian, Soviet, and Western alike, it marked the final adoption of the servile regime (krepostnoe pravo) in Russia and thereby the central role of the state in the process. ${ }^{17}$ Yet, if we read that document carefully, we find that it contains nothing concerning the organization of work on the estates. ${ }^{18}$ We find instead, in chapter is of the document, a section devoted to the trial of runaway peasants. The document mentions peasants and the rural population, but not serfs. The thirty-four articles making up its eleventh chapter define the rules governing runaways, which is to say peasants.

"Peasants" meant individuals, with or without land, who were members of any rural community, who were said to have moved outside their own rural districts without the permission of the landowner or the local public authority in order to settle in another rural district or place themselves under the authority of cities, monasteries, and so on. It refers to members of rural communities with obligations towards either private landowners or the state, or towards their rural community. ${ }^{19}$ In other words, like the other documents discussed earlier, the 1649 Ulozbenie aimed not so much to "bind" the peasantry as to grant state certification of the property rights of nobles over the land, and only on that basis to transfer property along with the population residing on it. Nobles were, therefore, able to demand payment of credit, work service, and the like, from rural inhabitants. However, exactly as they did before, peasants continued to sign "settlement contracts" 20 with landlords, in which they identified the

17. Hellie, Enserfment and Military Change in Muscovy.

I8. Blum, Lord and Peasant in Russia, pp. 262-265; A. Man'kov, Razvitie krepostnogo prava v Rossii vo vtoroi polovine XVII veka [The Development of Serfdom in Russia during the Second Half of the Seventeenth Century] (Leningrad, 1962).

19. A new Russian edition (Sobornoe ulozhenie I649 g.) and commentaries was published in 1987 under the supervision of A. Man'kov. For an English translation see Richard Hellie, Muscovite Society (Chicago, IL, 1967); idem, The Muscovite Law Code (Ulozhenie) of I649 (Irvine, CA, 1988); "The Law Code of I649" and "Muscovite-Western Commercial Relations", in Thomas Riha (ed.), Readings in Russian Civilization, 2nd edn (Chicago, IL, I969), pp. I54-172.

20. Hellie, Enserfment and Military Change in Muscovy, p. I44; E.I. Kamentseva, "Usloviia zakreposhcheniia novoporiadchikov" [The Conditions of Enserfment of New Settlers], Trudy moskovskogo gosudarstvennogo istoriko-arkbivnogo instituta, 7 (1954), pp. I29-I54. 
conditions and terms of their engagement. The contracts provided landlords with titles over peasants for use in case they ran away.

The question to be answered concerns the extent to which the provisions contributed to solving the long-term questions of land ownership and social status in Russia, and in particular the unfair competition between hereditary nobles with their practice of keeping "runaways" on the one hand, and the sharp conflicts between nobles in government service and hereditary nobles on the other hand, as well as the conflict between nobles and merchants. The available sources reveal a clear attempt by the state to enforce rules, ${ }^{21}$ but as litigation recorded among landowners and between landowners and urban merchants plainly shows, the legal definition of those who had the right to own and transfer populated estates was not made clear.

As a consequence, throughout the eighteenth century, differing rules were adopted to assess claims. Those rules took a clear position, determining the definition of "hereditary nobles". From the mid-I 730 os until the early I 760 s, a number of decrees limited the numbers of those entitled to own and transmit inhabited estates. Servants, servants in monasteries, ${ }^{22}$ soldiers and the lower administrative levels, the clergy, merchants, urban guilds, Cossacks, and raznochintsy (people of various ranks) were all prohibited from acquiring or transferring inhabited estates and from establishing krepost' relationships. ${ }^{23}$ Finally, in 1762 , factory owners were prohibited from buying and transferring estates with either urban or rural workers. ${ }^{24}$

In short, from the mid-sixteenth century until the last quarter of the eighteenth century Muscovite, Russian, and Imperial Russian rules of land ownership did not refer to serfs but mostly aimed to define who was entitled to own and then dispose of populated estates and, as a consequence of that entitlement, who could retain runaways. Attempts by nobles to limit access to land and status by other groups, such as service elites and the bourgeoisie, were constantly mitigated by the ambivalent

21. On peasant mobility, see Hellie, Enserfment and Military Change in Muscovy, pp. I42 ff.; Daniel Morrison, "Trading Peasants" and Urbanization in Eighteenth Century Russia: The Central Industrial Region (New York [etc.], 1987); E.I. Indova, "Rol' dvortsovoi derevni pervoi poloviny XVIII v. v formirovanii russkogo kupechestva" [The Role of the Village Court during the First Half of the Eighteenth Century in the Formation of a Russian Bourgeoisie], Istoricheskie Zapiski, 68 (1961), pp. 189-210, a French translation of which has appeared as "Les activités commerciales de la paysannerie dans les villages du tsar de la région de Moscou (première moitié du XVIIIe siècle)", Cahiers du monde russe, s (1964), pp. 206-228. Several examples of this can be found in RGADA, fond 294, op. 2.

22. PSZ (I), VIII, n. 5633. Blum, Lord and Peasant, pp. 358-362, on the debates and various drafts of these laws: RGADA, fond 342, op. I, delo 37, part 2.

23. PSZ (I), XII, nn. 9332, 9367.

24. PSZ (I), XV, n. I $1490 ; \mathrm{XVI}$, n. I 1638. 
approach of the state elite, which wished to allow, yet at the same time also restrict, access by the nobility, in order to win support for reform and ensure social stability.

That equilibrium changed during the final quarter of the eighteenth century, when "entitled" nobles seemed to become more and more interested in selling properties to non-noble elites, to present a loan as a sale or vice versa, mainly for tax reasons, but also in response for instance to financial difficulties or conflicts within the family. ${ }^{25}$ Of course, other nobles and the tsarist elites were opposed to such practices, for both sociopolitical and economic reasons. Nonetheless, in I836, nonhereditary nobles were confirmed in their right to own inhabited estates, though not to transfer them. ${ }^{26}$ Those provisions were followed by an increasing number of disputes among nobles, service nobles and hereditary nobles, and between nobles and the administration. According to the statistics of the Ministry of Justice, in 1845 alone 6,400 requests for confirmation of the title of "noble" were submitted, only half of which were validated. ${ }^{27}$

From that perspective, the rules paved the way to a closer focus on a legal definition of "illegal bondage". All transactions made between nobles and people who were not entitled to possess populated estates were illicit, and gave rise, therefore, to illegal possession and illegal bondage. A law in 1833 prohibited any new bondage, even if the parties agreed to it. ${ }^{28}$ Limitations imposed on the mobility of peasants residing on an estate owing to a debt to a non-noble were also forbidden. ${ }^{29}$ Several other rules followed during the first half of the nineteenth century, which in fact precipitated a broader process in which administrative and legal condemnation of bondage opened the way to large-scale administrative and judicial "emancipation".

\section{CHANGING LEGAL STATUS: ADMINISTRATIVE PROCEDURE OR COURT PROCEEDINGS}

The ways in which economic and social actors appropriate legal rules have been the subject of a huge number of studies in sociology, economics, history, and anthropology, and, of course, among legal scholars. In social and economic history, the same approach has been developed for different countries and different periods, and Russian studies too have recently

25. The High Chamber (senate) records several of those cases in I8I6; Arkhiv gosudarstvennogo soveta, 5 vols (St Petersburg, 1869-1904), IV, vyp. I, ch. 2, pp. 253-258.

26. PSZ (II), XI, n. 9203.

27. Otchet ministerstva iustitsii za I845 (St Petersburg, I846), p. xix.

28. Svod zakonov, IX, art 546 (1833).

29. Wirtschafter, Structures of Society, p. $8 \mathrm{I}$. 
developed similar methods of analysis. ${ }^{30}$ However, it is widely accepted that peasants had but few legal rights in eighteenth-century Russia; indeed, some scholars consider that to have been true right up to the legal reforms of I 864 .

Their arguments require a serious assessment. In fact, recourse to the law for capturing social and economic assets depends on the distribution of legal rights, as well as on legal procedures and on the precise wording of laws. In particular, it is true that peasants had no right of recourse to the law against their masters, but that situation had begun to change even before I 864, with the institution of peasant courts in the I770s. Those courts were certainly limited in their scope and effect, as they were controlled by landlords. At the same time, the difficulties faced by peasants in challenging their masters generally related to physical punishment and the organization of labour, which we shall examine in the next section. Legal rights on estates were easier to mobilize not only for other nobles or merchants, but also sometimes for peasants, with the encouragement of others who might have been interested in a particular estate. In fact, many laws were passed during the first half of the nineteenth century to facilitate administrative changes to the legal status of peasants. They were reforms that responded simultaneously to particular claims and worries at a given moment and to a more general attitude on the part of Russian elites. Political stability, economic efficiency, paternalistic criticism of serfdom, and the particular economic interests of the state or some of the nobility all played a part, to different degrees, in reform. ${ }^{31}$

In general, the matter of rules and their implementation consisted in transferring peasants belonging to private estates to the legal category of state peasants. After the seventeenth century, peasants on noble and private estates had been distinguished from state peasants. ${ }^{32}$ State peasants

30. The rapidly growing bibliography includes: Wirtschafter, Structures of Society; idem, Social Identity in Imperial Russia; and Virginia Martin, Law and Custom in the Steppe: The Kazakhs of the Middle Horde and Russian Colonialism in the Nineteenth Century (Richmond, 2001). Most of the available literature on legal action in Imperial Russia focuses on the post-1 864 period: Richard Wortman, Development of a Russian Legal Consciousness (Chicago, IL, I976); William Wagner, Marriage, Property and Law in Late Imperial Russia (Oxford, 1994); Jane Burbank, Russian Peasants Go to Court: Legal Culture in the Countryside, 1905-I9I7 (Bloomington, IN, 2004); Peter Solomon (ed.), Reforming Justice in Russia, I864-I994: Power, Culture, and the Limits of Legal Order (Armonk, NY, I997); and E.A. Pravilova, Zakonnost' $i$ prava lichnosti: administrativnaia iustitsiia $v$ Rossii, vtoraia polovina XIX v.-oktiabr' ${ }^{19 I 7}$ [Legality and the Rights of the Person: Administrative Justice in Russia, in the Second Half of the Nineteenth Century to October 1917] (St Petersburg, 2000).

31. Moon, Abolition of Serfdom in Russia; Blum, Lord and Peasant in Russia; Hoch, Serfdom and Social Control in Russia; Robert E. Jones, The Emancipation of the Russian Nobility, I762-I785 (Princeton, NJ, I973); and D. Saunders, Russia in the Age of Reaction and Reform, I80I-I 88 I (London [etc.], I992).

32. On this difference, see V.I. Semevskii, Krest'ianskii vopros $v$ Rossii $v$ XVIII i pervoi polovine XIX veka [The Peasant Question in Russia in the Eighteenth to the First Half of the 
had certain obligations only to the state, for example to pay an annuity, usually in money, sometimes in kind. They were also obliged to perform work of common interest, which is usually mentioned to justify the existence of forced labour and serfdom in this category. At the same time, state peasants could work in cities in trade and industry, provided they had the required documents. ${ }^{33}$ Catherine II even included representatives of state peasants in her legislative commission assigned to define the rights and obligations of the main social groups. ${ }^{34}$ In 1842 , state peasants were freed from any obligation towards the state, apart from tax.

Starting from that premise, we can study the rules allowing a peasant from a private estate to be reclassified as a state peasant. A first reform was adopted by Alexander I, who ascended the throne in I80I and gave the impression of being willing to introduce far-reaching reforms. In I $80 \mathrm{I}$ he allowed merchants, townspeople, and state peasants to own unpopulated estates, which he intended as a partial breaking up of the nobles' monopoly of landownership. In I 803 , a decree created the svobodnye kblebopashtsy, free farmers who at the discretion of the landowner were exempt from any obligation to him, apart from those obligations arising from the attribution to peasants of plots of land belonging to the overall owner. Those agreements were legally binding on both peasants and landowners. ${ }^{35}$

The influence of German and Russian intellectuals, as well as pressure from some among the noble elites, encouraged the reforming attitudes of the tsars, in particular Alexander, who was pushed to adopt that provision by Count Rumyantsev. Rumyantsev had sought permission to free some of his serfs and sell land to them, and the agreeable answer to his request became the basis for broader reform. This provision by Alexander was

Nineteenth Century], 2 vols (St Petersburg, I 888); idem, Krest'iane v tsarstvovanie Imperatritsy Ekateriny II [The Peasantry under the Reign of Catherine II], I, 2nd edn (St Petersburg, 1903 [first published I88I]), II (St Petersburg, I90I); I.I. Ignatovich, Pomeshchich'i krest'iane nakanune osvobozhdeniia [Private Landlords' Peasants on the Eve of Emancipation], 2nd edn (Moscow, I910), 3rd edn (Leningrad, I925); D.I. Raskin, "Ispol'zovanie zakonodatel'nykh aktov v krest'ianskikh chelobitnykh serediny XVIII veka. (Materialy k izucheniiu obshchestvennogo soznaniia russkogo krest'ianstva)" [The Appeal to Legal Acts in Peasant Petitions in the Mid-Eighteenth Century, in Materials for Studies of the Social Consciousness of Russian Peasantry], Istoriia SSSR, 4 (1979), pp. I79-192; M.A. Rakhmatullin, Krest'ianskoe dvizhenie v velikorusskikh guberniiakh v I826 I857 gg [Peasant Movements in the Grand Russian Provinces, r 826-1857] (Moscow, 1990).

33. N.M. Druzhinin, Gosudarstvennye krest'iane i reforma P.D. Kiseleva [State Peasants and the Reform of P.D. Kiselev] (Moscow, 1958). See too Struve, Krepostnoe khoziaistvo.

34. Sbornik imperatorskogo russkogo istoricheskogo obshchestva [Collected Essays of the Russian Historical Society], X (St Petersburg, I 872), pp. 28 5-288; Isabel de Madariaga, Russia in the Age of Catherine the Great (London, I98 I), p. I 39; Moon, "Reassessing Russian Serfdom", and idem, The Abolition of Serfdom in Russia.

35. PSZ (I), XXVII, n. 20620 (20 February I 803). 
supposed to lead to an improvement in agriculture while being advantageous to estate owners, and according to the estimates of Hoch and Augustine, between I 833 and I 855 alone 58,225 people were emancipated on the basis of it, ${ }^{36}$ a figure that rose to I I 4,000 male peasants between I 803 and I 855 . However, despite several attempts to go further, Alexander did not adopt other reforms of the same kind. The Napoleonic wars and opposition by some groups of nobles and high-ranking officials seem to have played a role in his change of heart. ${ }^{37}$

The next tsar too, Nicholas I, spent some time in projecting reforms before adopting concrete rules. They occurred in the broader realm of Kiselev's reforms between I 838 and I 842 , which radically modified the conditions of state peasants. Peasants' general and professional education was taken into account, while their fiscal burden and the obligations toward the state were no longer assessed per head, but in conformity with the value of each individual peasant's land or income from non-agricultural activities. ${ }^{38}$

Kiselev ordered a general enquiry into agriculture and the peasantry; its final report concluded that the labour of peasants with no statutory obligations to landowners was more productive than coerced labour. However, on the basis of that report, Kiselev and Nicholas I maintained that the present difficult situation of agriculture and the extent of coerced labour was the result of the fact that some landowners had abused their power and had extended the power of their patronage over the peasantry. Limitation of those abuses thus became a precondition for deeper reforms. At the same time, it was argued that peasants should not be freed from their illegal bondage without being given the opportunity to acquire their own land. In fact, as the reforms experienced in the Western borderland had proved, freedom without land would lead to a clear worsening of the peasants' circumstances and thence to social and political instability.

Accordingly, in 1842 a new decree was adopted. It was conceived as the direct descendant of the $180_{3}$ decree, but with the major difference that the contractual agreement between an estate owner and peasants would not be left to the free will of the former but would be regulated by law. If the peasants involved did not redeem the value of the land, estate owners would retain the right of full patrimonial ownership of it and the peasants would receive plots for their use. A particular category of peasant was created; they were the peasants with an obligation (obiazannye krest'ianie) towards noble landowners who fitted neither the category of private

36. S. Hoch and W. Augustine, "The Tax Censuses and the Decline of the Serf Population in Imperial Russia, I833-1858”, Slavic Review, 38 (1979), pp. 403-425.

37. Moon, Abolition of Serfdom in Russia, p. 42; S.V. Mironenko, Samoderzhavie i reformy: politicheskaia bor'ba v Rossii v nachale XIX v. [Autocracy and Reforms: Political Struggle in Russia in the Early Nineteenth Century] (Moscow, 1989).

38. Druzhinin, Gosudarstvennye. 
estate peasants in the strict sense (pomeshchichie krest'iane) nor that of servants (dvornye liudi).

As with previous rules, this new decree referred specifically to peasants, private peasants, and rural inhabitants, but not to "serfs", who would be subject to other legal rules (uslovnoe pravo); peasants no longer had any general obligations towards landowners, except those concerning the plot received when the contract with the property owner was signed. ${ }^{39}$ Peasants concluded contracts with landowners based on the size of their allotment and the level of their obligations. From the adoption of the new law until I 858 , a total of 27,173 male peasants, and their families, were affected by the decree. ${ }^{40}$ In $\mathrm{I} 84 \mathrm{I}$, peasants whom private nobles had allotted freely to monasteries or charitable institutions were also reclassified due to the prohibition on the ownership and transfer of serfs by those institutions. ${ }^{{ }^{\mathrm{I}}}$ About 8,900 people were thus transferred to the category of state peasants, and the institutions to which they belonged were compensated by the state. ${ }^{42}$

Tsar Nicholas did not cease his reforms; in I844, two new laws facilitated the reclassification of dvornye lindi (servants); the first one freed their masters from any responsibility for the payment of their taxes, while the servants freed were subject neither to military service nor taxation until the next revision. The second law facilitated a change in legal status in cases in which a landowner mortgaged his estate to certain credit institutions. According to a study at the time, in I85 I alone II,000 meshchane (merchants) from i I provinces were said to have benefited from those rules, having been previously the peasants of private owners. ${ }^{43}$ About 19,000 working peasants attached to private factories were freed between I 840 and I85I, and during the same period many mines had recourse to "temporary workers" (nepremennye or urochnye rabotniki), who were registered as private peasants at the time of the eighth revision. The facts were denounced years later and a court decision was made only for the ninth revision in $185 \mathrm{I}$. At that time, 53,900 men working in the mines were transferred to state estates as peasants. ${ }^{44}$ All those rules gave

39. PSZ (II), XVII, n. I 5462 .

40. Hoch and Augustine, "Tax Censuses and the Decline of the Serf Population", p. 4Io.

4I. PSZ (II), XVI, n. I4669, i9 June I84I.

42. Hoch and Augustine, "Tax Censuses and the Decline of the Serf Population", fn. p. 4ro;

N. Mel'nitskii, Sbornik svedenii o voennoo-uchebnykh zavedeniiakh v Rossii [Collection of Figures on the Military Establishments in Russia], 4 vols (St Petersburg, I857-I860), II, part 3, pp. I87, 2I7; part 4, pp. 52, II9; part 5, p. I4I.

43. P. Keppen, Deviataia reviziia: issledovanie o chisle zhitelei $v$ Rossii $v$ I 85 I goda [The Ninth Census: Study of the Number of Inhabitants in Russia in I851] (St Petersburg, 18 57), pp. 6-7, 21, 62, 88, 95, I00, I27, I42-I44, I 52-I 59 .

44. P.G. Ryndzinskii, "Vymiralo li krepostnoe krest'ianstvo pered reformoi i 86I g.?" [Were Serfs Really Disappearing Before the Reform of I861 ?], Voprosy istorii, 7 (1967), pp. 54-70. 
rise to a reclassification of private peasants into other categories, and thereby erased their obligations towards their landlords.

Administrative emancipation sometimes occurred for other reasons. As we have seen, under tsarist law mortgaged estates put up for auction were especially targeted. State and noble elites agreed that indebted landowners must be helped in order to prevent their lands from falling into the hands of "speculators" and bourgeoisie. To that end, along with the state itself, local peasants were granted priority in acquiring such lands. In I 847 , the peasants from auctioned estates could buy land and purchase their own freedom to move. ${ }^{45}$ That same year, however, the state Ministry of Estates, set up in 1838 , was obliged to buy private estates put up for auction. As a result, I 78 estates were taken over between 1838 and I 855 , with a population of about 58,275 serfs consequently transferred to the state. Beginning in $\mathrm{I} 842$, the same ministry also began taking over estates belonging to "isolated peasants" (odnodvorcheskie krest'iane). Until i 858 , about 8,000 peasants were taken over by the state in that way. In 1845 , the administration in charge of feeding horses in the province of Voronezh bought the estate of Count Orlov, with its 6,562 inhabitants, who became state peasants. The "public treasury" (udel) also took over estates: between I 83 I and I 860 it bought 52 estates in the provinces of Simbirsk and Orel, with about 25,000 inhabitants. In all, between I 833 and I 858 alone, the legal status of 343,575 male peasants changed owing to mass emancipations by the state: they ceased to be private estate peasants and became state peasants and sometimes meshchane.

General and administrative law regarding emancipation had a cumulative effect not only on mortgaged estates, but also on the terms of succession. Thus, two new laws adopted in I 836 and I 839 stipulated that if a landowner left no heirs, or no heirs who could legitimately own serfs, the peasants would become state peasants, whereas the servants could register in cities as meshchane..$^{46}$ In I $84 \mathrm{I}$, a new law prohibited the succession of landless nobles or landless owners of peasants. Consequently, between I84I and I 858 the number of landless nobles dropped from $\mathrm{I} 7,700$ to 3,633 and their serfs from 62,000 to $\mathrm{I} 2,045$, a dramatic fall even taking into account the possibility that some of the serfs had been sold to other nobles. ${ }^{47}$

The voluntary redemption of peasants' obligations and thus a change in legal status by the master was already provided for in the seventeenth and eighteenth centuries. It is, however, difficult to estimate the number of those redemptions as no systematic, province-by-province studies are

45. Wirtschafter, Social Identity in Imperial Russia, p. I $2 \mathrm{I}$.

46. Svod zakonov, IX, art. 462-463 (I857); PSZ (II), XI, n. 9203 (I836); XIV, n. I 3012 (I 839).

47. Hoch and Augustine, "Tax Censuses and the Decline of the Serf Population", p. 420. 
available, although notarial archives (krepostnye knigi) and estate archives provide useful information. The impression given by the huge mass of archives is that voluntary acts of redemption accelerated during the nineteenth century in response to both tax support and legal simplification as provided by the tsarist rules. ${ }^{48}$ According to estimates at the time, the ninth revision of $185 \mathrm{I}$ held in $\mathrm{I} 2$ provinces (guberniia) resulted in a change in the legal status of I I,000 meshchane. ${ }^{49}$ Though not cumulative, relatively detailed data on those individual acts was collected by the tsarist authorities between I 860 and I868; they cover 25 volumes and give a wealth of information on the state of the population in Russia's provinces and in its empire. ${ }^{50}$ These acts were part of the paternalistic relationships proper to the system; they set an example for the mass of peasants to engage in cordial relations with their landowners with a view to their possible emancipation. The pace of those acts accelerated during the nineteenth century in response to incentives from the authorities and the compensation guaranteed to noble landowners. ${ }^{\text {I }}$

However, changing legal status also resulted from the increasing number of legal proceedings brought by peasants themselves against their masters. Until the I770s, there were no special courts in Russia for peasants, who were forced to apply to nobles and their courts to request emancipation, which considerably reduced attempts to initiate proceedings. The situation changed in 1775 with the introduction of peasant courts, accompanied by a clear-cut legal separation between ownership of things and rights over human beings. Throughout the nineteenth century, those issues were frequently the subject of court rulings. Peasants themselves were sometimes able to demonstrate in court that the landowner, or master, concerned was not entitled to own the estate. ${ }^{52}$ Proceedings brought by peasants became so numerous that between I 837 and I 840 the senate actually decided to put a stop to cases involving serfs still living with their masters. ${ }^{53}$ Overall, between 1833 and I 858 the senate recorded I 5,153 cases of illegal bondage, while the provincial courts dealt with 22,000 cases of this type. ${ }^{54}$ Naturally, these positive outcomes should not

\footnotetext{
48. Notarial archives in RGADA, fonds 6I 5 , op. I; fonds 1253 and $\mathrm{I} 274$.

49. Keppen, Deviataia reviziia, pp. 6, 7, 21 , 88, 95-100, I27, I42-144, I 52, I 59.

50. Glavnyi General'nyi Shtab, Materialy dlia geografii i statistiki Rossii, sobrannye ofitserami general'nogo shtaba [Materials for the Geography and Statistics of Russia, Collected by the Officers of the General Headquarters], 25 vols (St Petersburg, I860-I 868).

5. PSZ (II), XI, n. 9203.

52. TsGIAM, fond 54 (Moskovskoe gubernskoe upravlenie), I783-1917, op. I, for example 56, 284, 966, I 509. Several other cases can be found in Deistviia Nizhegorodskoi gubernskoi uchenoi arkhionoi komissii, several booklets, 1890 s.

53. RGIA, f. I I49, op. 2, delo 90; Wirtschafter, Structures of Society, p. 84.

54. PSZ (II), XX, n. I9283; XXII, n. 20825, RGIA, fond i I49, op. 3, delo i 25 . See too Hoch and Augustine, "Tax Censuses and the Decline of the Serf Population".
} 
obscure the difficulties confronting peasants who tried to bring proceedings against a noble or someone claiming to be noble. The rulings of local courts often differed considerably, and several judges considered peasant petitions inadmissible and even refused to grant them the right to appeal. ${ }^{55}$ A number of cases of corruption of judges by noble landowners were also recorded. Finally, the investigations of proceedings went slowly and it often took ten years to reach a conclusion. ${ }^{56}$

To sum up, like a number of other historians of Russia (Wirtschafter, Hoch, and Moon particularly), it is our contention that the abolition of serfdom in Russia cannot be traced to a single act (the emancipation statute of I86I) but has to be seen as a long-term process, started no later than the turn of the nineteenth century. At the same time, we go further and add another dimension, by examining the way in which rules actually defined the main social actors and the use those groups or individuals made of the rules. In our perspective, the opposition between "reforms from above" and bottom-up processes does not make sense insofar as the rules were adopted and implemented by different actors, with different interests. In other words, there is no "real life" beyond rules in as much as rules are not only "reference books" but shape the psychological and practical horizons and expectations of socioeconomic players.

In particular, serfdom and enserfment were never defined as such in tsarist legal rules. A large part of the peasant population was initially limited in its movements by contractual rules, which were then transformed into conditions of status. The rules defined the limitations on peasant movement resulting from their obligations to noble landowners or to the state, and represented a form of servitude but not the serf de la glèbe. The legal definition always retained its contractual and status aspects, however, which allowed it to be distinguished from slavery in the strict sense, by likening it to long-term forms of indenture, as with the status of certain miners in Scotland for example. The specific feature of "serfdom" relationships in Russia was that they referred not to bilateral relationships between nobles and peasants or between peasants and the state, but to a multilateral classification process involving craftsmen and peasants, noble landowners, meshchane, tsarist administrative directors, and judges. All that meant that the legal rights of peasants were limited, compared with those of elites, but also that they were not completely non-existent, as the changes in their legal status testify.

55. RGIA, fond I I 49, op. 2 delo 20. In particular, the lack of documentation was one of the most widespread arguments for rejecting petitions; Wirtschafter, Structures of Society, pp. 79, II 9 .

56. In particular, the law of 1847 , in PSZ (II), XXII, n. 20825 ; Wirtschafter, Structures of Society, p. 84 . 
That has implications for our interpretation of the reforms of I86I and the long-term trend for the Russian peasantry. At the time of the I86I reforms, peasants on private estates made up about half the total peasantry; of those, fewer than a half - in fact about 37 per cent of the whole population - were still required to provide corvées. ${ }^{57}$ Consequently, the end of "coerced labour" affected barely a quarter of all Russia's peasants. The obligations on landowners of this sizeable portion of the Russian population were transformed; what had become a genuine status was turned into chronic indebtedness to the state. From that perspective, the reforms of I 86I have to be seen in a broader context made up of several reforms implemented over a century and a half, and in any case aiming not to abolish "serfdom" so much as to change forms of power and hierarchies in the countryside. In particular, the reforms dealt with the legal entitlement of estate owners on the one hand, and forms of bondage on the other.

The reforms of I86 I did not mark a caesura, in that "serfdom" did not exist as such before, and legal constraints on peasant mobility and peasant labour did not disappear after i86I. In particular, the obligations on peasants to work did not disappear in I86I, although they continued to become less onerous, as they had during the first half of the century. Before that date, labour as a service defined the legal status and obligations of peasants and manufacturing serf workers towards estate owners. Undue statutory labour services were linked to the entitlement of the estate owner and the civil status of the peasant. After I86I, temporary obligations remained in force until they might be redeemed, while, on the industrial labour market, labour was mostly conceived as a service, and criminal penalties regulated any breach of contract by the worker. Consequently, despite the view still widespread in comparative analyses of forced labour, we would claim that Russia does not constitute an exception in the global history of emancipation, where the usual pattern was a gradual ending of coerced forms of labour rather than their sudden abolition. ${ }^{8}$ The question that prompts then concerns the specificity of the Russian path. We shall consider that first in relation to other areas experiencing the "second serfdom" and then in relation to the legal status of labour elsewhere in Europe.

57. Koval'chenko, Russkoe krepostnoe krest'ianstvo v pervoi polovine 19th v.; Hoch and Augustine, "Tax Censuses and the Decline of the Serf Population".

58. On this, see inter alia Martin Klein (ed.), Breaking the Chains: Slavery, Bondage, and Emancipation in Modern Africa and Asia (Madison, WI, 1986); and P.C. Emmer (ed.), Colonialism and Migration: Indentured Labour Before and After Slavery (Dordrecht, 1986). A full bibliography on emancipation can be found in Rebecca Scott, Thomas Holt, Frederick Cooper, and Aims McGuinness, Societies after Slavery: A Select Annotated Bibliography of Printed Sources on Cuba, Brazil, British Colonial Africa, South Africa and the British West Indies (Pittsburgh, PA, 2004). 


\section{THE LEGAL STATUS OF LABOUR IN THE EIGHTEENTH AND NINETEENTH CENTURIES: A COMPARATIVE APPROACH}

The conclusions we have reached for Russia are quite similar to those recently advanced for Brandenburg and Bohemia. In contrast to the traditional orientations of historiography, the period from I650 to i 800 saw a fundamental transformation in Gutsherrschaft and its legal relations well before the reforms of the early nineteenth century. ${ }^{59}$ In Brandenburg, villagers were not designated as "serfs" but rather as "subjects" (Untertanen). ${ }^{60}$ Forms of personal serfdom (Leibeigenschaft) did exist in German east Elbia, but, still, the term "unlimited labour services" actually entailed specific limits and numerous disputes related to those occurred in law courts between peasants and landlords as early as in the seventeenth century. The subjection of village farmers did not restrict their right to hold and transmit property, contract marriages, nor take action in courts of law.

That is to say that the translation of Untertanen, which really means "subject", as "serf" is misleading; the dependency the terms described was not a personal attribute but rather a consequence of occupying a farm from which unpaid labour service could be claimed. ${ }^{61}$ The enlightened autocracy of Frederick II (I740-I786) took steps to abolish hereditary subjection in villages, widen the rural commoners' access to royal appellate courts, limit noble enclosure of village land, reduce labour services, and register the manorial obligations of villages in legally enforceable contracts. ${ }^{62}$ The very fact that the law sanctioned heavy dependence of peasants on landlords was not inconsistent with the raising of legally "free" villages, something which was true not only of Brandenburg but also of other regions in east central Europe. For example, half of peasant households in late sixteenth-century Poland kept farm servants. ${ }^{63}$ In Schleswig-Holstein, Mecklenburg, Swedish Pomerania, and Lusatia

59. Edgar Melton, "The Decline of Prussian Gutsherrschaft and the Rise of the Junker as Rural Patron, 1750-1 806", German History, I 2 (1994), pp. 334-350; idem, "Population Structure, the Market Economy, and the Transformation of Gutsherrschaft"; William Hagen, "Village Life in East-Elbian Germany and Poland, I400-I 800", in Tom Scott (ed.), The Peasantries of Europe: From the Fourteenth to the Eighteenth Centuries (London, 1998), pp. 145-190; and Sheilagh Ogilvie, "Communities and the 'Second Serfdom' in Early Modern Bohemia", Past E Present, I 87 (2005), pp. 69-I I9.

60. William W. Hagen, Ordinary Prussians: Brandenburg Junkers and Villagers, I500-1840 (Cambridge, 2002).

61. Ibid., pp. 36-37.

62. Hagen, "Village Life in East-Elbian Germany and Poland", p. I49.

63. Robert Frost, "The Nobility of Poland-Lithuania, I 569-1795", in Hamish Scott (ed.), The European Nobilities in the Seventeenth and Eighteenth Centuries, II, Northern, Central and Eastern Europe, (London, 1995), pp. I83-222; Hagen, "Village Life in East-Elbian Germany 
severe forms of personal dependency were widespread, ${ }^{64}$ and the line separating the free from the subject farmers began to blur, especially where, as in Brandenburg-Prussia, commutation payments increasingly eclipsed the value of labour services.

As in Russia, the government encouraged changes in the legal status of peasants. ${ }^{65}$ Legal intervention was important during the last quarter of the eighteenth century and it was not rare to find peasants taking their cases to the appellate court in Berlin. ${ }^{66}$ In turn, that in itself gives further confirmation of the specific access to capitalism in the eastern Elbe region, where both proto-industry and peasants' multiple activity as well as the Junkers" "commodification" found in the evolving institutional environment a crucial resource. ${ }^{67}$ At least from the point of view of legal categories and practices, the notion of "second serfdom" has to be revisited, exactly as had been done with medieval serfdom after Marc Bloch's seminal paper in I92 I. Bloch warned against the use of the word "serf" and the expression serf de la glèbe. He showed in particular that the concept was absent in the Middle Ages and, indeed, only enjoyed success after Montesquieu's De l'Esprit des lois in 1748. From that point of view, the serf de la glèbe was used to identify a largely stylized feudal system and to oppose it to an equally stylized liberal economic system. ${ }^{68}$

If all that is true, we might ask to what extent this heritage of labour as service migrated into the industrial notion and legal definition of labour. During the first half of the nineteenth century, patrimonial courts strongly sanctioned farm labourers who moved without their landowner's permission. ${ }^{69}$ Prior to initial unification, Germany adopted rules similar to those in the French civil code, distinguishing the renting of work from

and Poland"; idem, "Capitalism and the Countryside in Early Modern Europe: Interpretations, Models, Debates”, Agricultural History, 62 (1988), pp. I 3-47.

64. Hagen, "Village Life in East-Elbian Germany and Poland", p. I75.

65. Hartmut Harnisch, "Bäuerliche Ökonomie und Mentalität unter den Bedingungen den orstelbischen Gutsherrschaft in den letzten Jahrzehnten vor Beginn der Agrarreformen", Jabrbuch für Wirtschaftsgeschichte, 24:3 (1989), pp. 87-108.

66. Idem, Kapitalistische Agrarreform und Industrielle Revolution (Weimer, 1989).

67. Terence J. Byres, Capitalism from Above and Capitalism from Below: An Essay in Comparative Political Economy (London, 1996); Shearer David Bowman, Masters \& Lords. Midorgth Century US Planters and Prussian Junkers (New York, 1993); Peter Kriedte, Peasants, Landlords and Merchant Capitalists: Europe and the World Economy, I500-I800 (Cambridge, 1983).

68. Marc Bloch, "Serf de la glèbe. Histoire d'une expression toute faite", Revue historique, 36 (192I), pp. 220-242.

69. Monika Wienfort, "Administration of Private Law or Private Jurisdiction? The Prussian Patrimonial Courts, 1820-1848", in Willibald Steinmetz (ed.), Private Law and Social Inequality in the Industrial Age: Comparing Legal Cultures in Britain, France, Germany and the United States (Oxford, 2000), pp. 69-88. 
the renting of service. ${ }^{70}$ Most contracts emphasized service, and therefore the selling of "labour time", rather than the results of the work itself. ${ }^{7 \mathrm{I}}$ In keeping with that approach, significant criminal sanctions were provided for in the labour law of the main German states, in Prussia, and then in the Reich. In the I845 Law on Industry, the criminal sanctions concerning labour were justified, exactly as they were in Great Britain, in terms of the freedom of economic activity and of contracts. More specifically in Prussia, employers treated unpunctual attendance as a withholding of labour power whose loss could be calibrated and precisely counterbalanced. That not only graduated the fine, it also gauged the value of the time lost. ${ }^{72}$ The attention devoted to time was consistent with the notion of labour as service - work time was a continuous process of converting labour power into an output.

In Germany, major reforms took place at the turn of the twentieth century, linked to the emergence of the welfare state, the "social question" in public debate, and the rise of socialism. Criminal sanctions were repealed in 1869 , but only for wage-earners in the industrial sector; they were maintained for domestics and agricultural labourers until the early twentieth century. With regard to labour, the new civil code adopted in I896 bore only a superficial resemblance to previous codes and to the French model. The worker's loyalty corresponded to the employer's obligation to "take care" of his workers. The "new" labour contract shifted from contract and tort law to the law of persons, but in any event labour was still viewed as a service; technical rules and workshop regulations therefore remained important. ${ }^{73}$ The change in labour from contract to status, from contractual freedom to social protection, took place while the link between labour and service provision was maintained. ${ }^{74}$

Was that link between labour and service specific to "central" and "eastern" Europe, or was it widespread in other European countries too? In view of those elements, and contrary to any common view, it would be difficult to compare Anglo-Saxon "free labour" to guilds and other types of constraint in France and Germany. Thus, from the sixteenth to the nineteenth century, rules on runaways were adopted not only in the colonial Americas for slaves and indentured workers, but also in Great

70. A. Supiot, Critique du droit du travail (Paris, 2002); V. Sims, "Good Faith in Contract Law: A Comparative Analysis of English and German Law" (unpublished Ph.D. dissertation, University of Cambridge, 2002).

7I. Richard Biernacki, The Fabrication of Labor: Germany and Britain, 1640-19I4 (Berkeley, CA, I995).

72. Ibid., p. II3.

73. S. Simitis, "The Case of the Employment Relationship: Elements of a Comparison", in Steinmetz, Private Law and Social Inequality in the Industrial Age, pp. I 8 I-202.

74. S. Simitis, "Juridification of Labor Relations", in G. Teubner (ed.), Juridification of Social Spheres (Berlin, I987), pp. I I3-16r. 
Britain, where runaway workers, journeymen, and so on were submitted to quite similar rules under the Master and Servants Acts and the Statute of Artificers of is 62. Apprenticeship, advances in wages and raw materials, and also simple master-servant relations justified such provisions. From the sixteenth to the end of the nineteenth century, in Britain and Europe, free labour was, despite the existence of a contract, considered the "property" of the employer and a resource for the whole community to which the individual belonged. ${ }^{75}$

In Britain, the Statute of Labourers of I350-I35I was enacted two years after the contract clause of the ordinance of labourers had been put in place. ${ }^{76}$ The Statute of Artificers and Apprentices, adopted in 1562, controlled apprenticeship until I $8 \mathrm{I}_{4}$. The reform of I $_{\mathrm{I}} \mathrm{4}$, usually presented as the rise of liberal market control, especially of labour, had no effect on the contractual aspects of the labour relationship. From the I720s and throughout the nineteenth century, a number of laws were adopted to strengthen criminal sanctions in the event of breach of contract, especially by the worker, and penalties were laid down for those who refused a job. ${ }^{77}$ On the whole, workrelated criminal sanctions were reinforced between 1720 and I850, being combined in the Master and Servants Acts. Wage-earners were considered domestic servants and were above all supposed to provide a service. ${ }^{78}$ The labour of servants was usually conceived as a master's property.

All the same, one has to be careful when defining "servants". Like many lawyers, MacPherson refers to all forms of wage labour, ${ }^{79}$ while Peter Laslett limits it to domestic servants. ${ }^{80}$ Indeed, as Steinfeld has demonstrated, the word "servant" took on multiple meanings at different times, and the labour relationship did not consist of a single homogeneous legal status. For example, between the fourteenth and sixteenth centuries contemporaries limited the word "servant" to particular wage workers who resided with their master, so labourers and artificers were excluded from its meaning. However, from the sixteenth century onwards, "servant" was increasingly used to define any sort of wage-earner and thus included

75. Steinfeld, Invention of Free Labor, especially ch. 3; M. Postan, "The Chronology of Labour Services", Transactions of the Royal Historical Society, 20 (1937), pp. 169-193.

76. Steinfeld, Invention of Free Labor, p. 30; Ann Kussmaul, Servants in Husbandry in Early Modern England (Cambridge, 1981).

77. D. Hay and N. Rogers, Eighteenth-Century English Society: Shuttles and Swords (Oxford, I997); D. Hay, "Master and Servant in England: Using the Law in the Eighteenth and Nineteenth Centuries", in Steinmetz, Private Law and Social Inequality in the Industrial Age, pp. 227-264.

78. S. Deakin and F. Wilkinson, The Law of the Labour Market: Industrialization, Employment, and Legal Evolution (Oxford, 2005), p. 45.

79. C.B. Macpherson, The Political Theory of Possessive Individualism: Hobbes to Locke (Oxford, 1962).

80. Peter Laslett, The World We Have Lost (New York, 1965). 
journeymen, artificers, and other workmen. ${ }^{81}$ Confusingly, from the late eighteenth century, domestic servants were excluded by judicial decision from the scope of master and servants statutes, at least in England, although in the colonies they were usually included. ${ }^{82}$ Special varieties of contract existed for mining, where an annual "bond" was in use, and shipping, where seamen's labour agreements were widespread.

The criminal measures accompanied the emphasis placed on contractual free will as a foundation of the labour market. Criminal sanctions were provided for because labour was free and the worker freely agreed to them. The measures were also applied to journeymen, unskilled workers, and in general whenever short-term contracts to improve output were involved. Insubordination or failure to comply with workshop production rules were also presented as a breach of contract without notice and as such were liable to criminal sanctions. ${ }^{83}$ In other words, application of criminal law to labour was aimed at reducing both turnover and supervision costs. ${ }^{8}{ }^{8}$ Monetary or raw material investments made by the employer were used to further justify such sanctions against wage-earners who left their jobs. ${ }^{85}$ Increasingly harsh labour laws were in fact applied; as recent quantitative and qualitative analyses show, between 1750 and I 875 the rules governing labour and the interpretations of the courts became more unfavourable towards wage-earners. ${ }^{86}$ At the same time, the master and servants laws reflected the concerns of the central state about social and political stability. The penal clauses and wage-recovery elements of the law were deeply embedded in poor law policy, the control of vagrancy, and the setting of wages. ${ }^{87}$ In contrast, until i 844 employers were never threatened with imprisonment for breach of contract. ${ }^{88}$

81. Steinfeld, Invention of Free Labor, pp. 17-22.

82. P. Craven and D. Hay, "The Criminalization of 'Free' Labour: Master and Servant in Comparative Perspective”, Slavery and Abolition, I 5:2 (1994), pp. 71-10I.

83. D.C. Woods, "The Operation of the Master and Servants Act in the Black Country, I 858-1875", Midland History, 7 (1982), pp. 93-1 I5; G. Barnsby, Social Conditions in the Black Country, I800-1900 (Wolverhampton, I980).

84. Michael Huberman, Escape from the Market: Negotiating Work in Lancashire (Cambridge, I996).

85. Woods, "Operation of the Master and Servants Act"; M.R. Freedland, The Contract of Employment (Oxford, 1976); D. Galenson, "The Rise of Free Labor: Economic Change and the Enforcement of Service Contracts in England, I35I-I875", in J. James and M. Thomas (eds), Capitalism in Context: Essays on Economic Development and Cultural Change in Honor of R.M. Hartwell (Chicago, IL, I994), pp. I I4-137.

86. Hay, "Master and Servant in England". See also Craven and Hay, "Criminalization of 'Free' Labour".

87. Hay, "Master and Servant in England", p. 80.

88. Douglas Hay, "England, I 562-I875: The Law and its Uses", in Douglas Hay and Paul Craven (eds), Masters, Servants and Magistrates in Britain and the Empire, 1562-1955 (Chapel Hill, NC, 2004), pp. 59-I I6, 67. 
Even if the poor law system of hiring was abolished in 1844 , it was not until I875 that criminal sanctions concerning labour contracts were abolished too and, even then, genuine measures to protect labour were not adopted until the next century, ${ }^{89}$ including those pertaining to occupational industrial accidents..$^{9 \circ}$ It was not before the mid-nineteenth century that a general theory of contract employment informed new legislative activity. It is only in the decisions of the early twentieth century that the courts can first be seen applying the contractual model, which they had developed for the middle classes, to industrial workers too, as well as to agricultural labourers and domestic servants. ${ }^{9 \mathrm{I}}$

Thus, the long-term movement of labour and its rules in Great Britain hardly confirms the traditional argument that early labour freedom in the country supported the industrial revolution. On the contrary, the latter was accompanied by increasingly tough regulations and criminal sanctions with regard to workers. The removal of criminal sanctions from the individual employment relationship in the I870s was soon followed by the first legislative interventions of the welfare state, beginning with the Employers' Liability Act of I 880. Before that time, the idea of contract of employment as a mechanism for expressing reciprocal obligations of employers and employees had developed only for professional and managerial workers. Indeed, this distinction ceased only when collective bargaining and social legislation extended their influence over the employment relationship. ${ }^{92}$

The process is particularly clear in the legal history of the indenture contract. As Steinfeld has brilliantly demonstrated, indentured servitude has been considered primarily a form of contractual freedom. Under colonial and later state statutes related to servants, masters could recover runaway servants, were authorized to administer corporal punishment, and could withhold their consent to their servants marrying. ${ }^{93}$ In political imageries, although not in law, indenture ceased to be considered a form

89. Huberman, Escape from the Market; Robert Steinfeld, Coercion, Contract, and Free Labor in the Nineteenth Century (Cambridge, 200I), p. 72; Deakin and Wilkinson, Law of the Labour Market; Steinmetz, Private Law and Social Inequality in the Industrial Age; S.F.C. Milsom, A Natural History of the Common Law (New York, 2003); M.R. Freedland, The Personal Employment Contract (Oxford, 2003).

90. On the evolution of Britain's rules on workers' health, see P.W. Bartrip and S. Burman, The Wounded Soldiers of Industry: Industrial Compensation Policy, I833-I897 (Oxford, 1983); P.W. Bartrip, Workmen's Compensation in Twentieth Century Britain: Law, History and Social Policy (Aldershot, 1987); and E.P. Hennock, British Social Reform and German Precedents: The Case of Social Insurance, I880-1914 (Oxford, I987).

91. Deakin and Wilkinson, Law of the Labour Market, p. 80.

92. Ibid., p. I07.

93. Steinfeld, Invention of Free Labor, p. I I. See also Richard Brandon Morris, Government and Labor in Early America (New York, 1946), and David Galenson, White Servitude in Colonial America: An Economic Analysis (Cambridge, 198I). 
of free contract at the same moment as "serfdom" was clearly identified in the "East". In fact, indenture was at the same time fully embedded in the legal culture of the Master and Servants Act and not so far removed from forms of coerced labour in Russia. At the same time, its evolution was linked to that of criminal penalties in labour contracts. By perhaps the mid-eighteenth century the contracts of ordinary native-born adult workers could no longer be enforced by recourse to criminal law, but the contracts of white imported indentured servants still could, although by the I 83 os those contracts too were no longer likewise enforceable. Only minors and black people continued to be exposed to criminal sanctions, and those practices regarding black people were not eliminated until the beginning of the twentieth century.94

At the same time, the legal provisions interacted with the economic features of indenture. From that perspective, one can distinguish a first phase, from the seventeenth century until i 830 , from a second phase, which lasted from the nineteenth and into the twentieth century. The first phase mostly involved some 300,000 indentured Europeans, occurred when slavery was still in place, and was organized mainly by merchants. Indentured labour went to tobacco plantations, and into manufacturing. The second phase involved 2.5 million non-Europeans, mostly Indians and Chinese but also including Japanese, Africans, and Pacific islanders, and indentured workers were employed in sugar production and manufacture. Unlike the first phase, they barely entered the "free" world at the end of their contract and retained their "unfree" engagement. ${ }^{95}$ However, within this common European, if not quite global, link between labour and service, France seems to be a partial exception, not so much as regards the notion of labour, but in the lack of criminal sanctions against breach of contract.

\section{A FRENCH EXCEPTION?}

In fact, in France, the notion of a work contract, and hence that of a "wage-earner" as we know it today, did not exist until the end of the nineteenth century. In eighteenth-century France, labour was considered a lease. ${ }^{96}$ Jurisprudence gave no definition of wage as there was no clear difference in status between hiring out labour and hiring out a

94. Steinfeld, Coercion, Contract, and Free Labor.

95. David Northrup, Indentured Labor in the Age of Imperialism, I834-I922 (Cambridge, 1995); and Galenson, White Servitude in Colonial America. See also Michael L. Bush, Servitude in Modern Times (Cambridge, 2000), and Hugh Tinker, A New System of Slavery: Export of Indian Labour Overseas, I830-I920 (London, 1974).

96. Jean Domat, Les lois civiles dans leur ordre naturel (Ist edn, I697), reprinted in Cuvres (Paris, I835), I; R. Pothier, Traité du contrat de lonage (Paris, I86I). 
commodity. ${ }^{97}$ The case of domestic servants was different because they were engaged for a longer period, usually a year or more, and their wage was the price of their engagement; the law at the time often considered their position akin to slavery. ${ }^{98}$ In that context, the act of apprenticeship was analogous to the primordial alienation of natural liberty. ${ }^{99}$

Agricultural labourers were not necessarily journeymen, but were often engaged as servants and as such they were supposed to complete a given task, such as the year's harvest. ${ }^{100}$ As in Russia and other countries in modern times and in the nineteenth century too, supervision was the biggest difficulty in the organization of labour in agriculture. The problems of supervising and motivating servants were compounded by the possibility that the servants could leave. As Philip Hoffman has stressed, historians have ignored such mobility in the early modern countryside, largely because demographers have noted the tendency of peasants to marry in their home villages. Various contractual arrangements sought to address the problem, with for example some tasks, such as some types of harvesting, being payable through piecework rates, while honesty and assiduousness could be rewarded with a wage raise. ${ }^{\text {IOI }}$ Most important, as in Russia, in modern France between the sixteenth and eighteenth centuries year servants and labourers had the right to move, with no penalties nor fees to pay - apart from in the period around St Martin's Day (I I November), between the end of the great labours of the autumn and the beginning of winter. ${ }^{102}$

As in Britain, in France indentured labour in the colonies (engagés) developed on the basis of the ordinary free labour contract. Indentured workers were subject to criminal sanctions, for instance "desertion" applied not only to convicts, but to ordinary indentured workers too, and the contracts of indentured individuals could be sold on. During the seventeenth and eighteenth centuries indentured labour targeted the Antilles and Canada, ${ }^{103}$ with 5,200 indentured servants leaving from La Rochelle alone for the

97. M. Sonenscher, Work and Wages: Natural Law, Politics and the Eighteenth-Century French Trades (Cambridge, 1989), p. 70.

98. La domesticité est une sorte d'esclavage, Encyclopédie méthodique, Jurisprudence, IX (Paris, 1789), p. I5. On this see Sara Maza, Servants and Masters in Eighteenth-Century France: The Uses of Loyalty (Princeton, NJ, 1983), and Jean-Pierre Gutton, Domestiques et serviteurs dans la France de l'Ancien Régime (Paris, 1981).

99. Sonenscher, Work and Wages, p. 75.

ı०0. Jean-Marc Moriceau, "Les Baccanals ou grèves des moissonneurs en pays de France (seconde moitié du XVIIIe siècle)", in Jean Nicolas (ed.), Mouvements populaires et conscience sociale (Paris, I985), pp. 420-433.

Ior. Philip T. Hoffman, Growth in a Traditional Society: The French Countryside, I450-I8IS (Princeton, NJ, 1996), pp. 45-46.

I02. Ibid., p. 47.

I03. Louise Dechêne, Habitants et marchands de Montréal an XVIIe siècle (Paris, 1974); Gabriel Debien, Les engagés pour les Antilles, I634-I7IS (Paris, 1952); and Fréderic Mauro, "French Indentured Servants for America, I 500-1800", in Emmer, Colonialism and Migration, pp. 83-104. 
Antilles between I660 and I7I I . However, that is far less than the estimated $2 \mathrm{I0}, 000$ servants and indentured emigrants leaving the British Isles to work in the New World colonies between I630 and 1700. ${ }^{104}$

The French Revolution abolished slavery, but only for a few years; its ultimate abolition came about only in I 848 and, even after that date, coerced labour was in use widely in the colonies, while indentured labour saw a revival. The contracts of engagés for Réunion, for example, included corvées and limited the length of the working day to between nine and ten hours, but the individual engagé was supposed to be at the master's full disposal. ${ }^{\text {IOS }}$ Such provisions were not necessarily "illegal" because, although the French Revolution suppressed lifetime engagement, it did not abolish the notion of labour as service. Instead of a work contract, there were two contracts provided for by the civil code: the lonage d'ouvrage - renting of work in the sense of a piece of work or completed task - and the lonage de service - the renting of "service".

The first type of contract considered the worker as an independent artisan who provided his own tools and was expected to produce a certain result within a certain time, while by contrast the second covered the provision of a "service" for a certain amount of time, and was a legacy of the relationship between service and domesticity characteristic of the ancien régime. ${ }^{106}$ When the renting of work was involved, the contract was often a written one, and the owner could terminate it by compensating the contractor. In the case of an accident, the employer had no objective liability, only a liability for negligence. However, when the renting of service was involved, the employer was the real contracting authority if the question of his liability arose in the event of an accident. ${ }^{107}$ The contract would most probably have been oral, and whereas the employer's word would have been sufficient for legal purposes, the wage-earner had to provide written proof. In any case, whether renting of work or renting of service was concerned, in accordance with the principle of contractual freedom, a judge was not allowed to intervene in setting wages. ${ }^{108}$ In that context, labourers were considered most often as people rented for service and their task was relatively unimportant compared to the time span of their renting. ${ }^{\text {109 }}$ However, that well-understood

104. Galenson, White Servitude in Colonial America.

I05. Hubert Gerbeau, "Engagées and Coolies on Réunion Island: Slavery's Masks and Freedom's Constraints", in Emmer, Colonialism and Migration, pp. 209-236.

I06. A. Cottereau, "Droit et bon droit. Un droit des ouvriers instauré, puis évincé par le droit du travail”, Annales, 57 (2002), pp. I 52 I-I 560.

I07. F. Gueugnon, M.C. Revol, and E. Serverin, Une analyse sociologique de jurisprudence: la réparation des accidents de travail, ${ }_{1840-1913}$ (Lyons, I983).

I08. Cass. Civile, I 2 December I 853, Sirey, Recueil générale des lois et des arrets (1854), I, I33. I09. For local labour relations and customs during the revolutionary period: AN (National Archives) F I 2 I5 I6 to I 544; AN F I0 45 I-2. Parliamentary reports on local customs in I848 are in 
legal and economic classification was not always respected, and so it was possible that labourers might be engaged for a certain task over a certain period. That was then de facto lonage d'ouvrage, even if it was not admitted as such, being in fact practised to escape the legal constraints of de jure lonage d'onvrage.

Day labourers were especially widespread in the Midi and Mediterranean area, in Alsace-Lorraine, in Île-de-France, and Picardy. In I 862 day labourers were estimated to comprise about half of the four million wage-earners in agriculture. Thirty years later the number of day labourers had fallen to I.2 million, mostly as a result of the sharp decline between I 862 and I892 in the number of labourers possessing small farms. ${ }^{10}$ In turn, servants (domestiques) accounted for an increasing proportion of hired people in agriculture. Their contracts were supposed to last about a year, or sometimes six or eight months, in which their circumstances were different from those of domestic servants, who were engaged for far longer periods. According to most local customs, servants were "subject to the will of the master", who owned as his property all the labour time of the servant during the entire period of service. The servants' gage (not "wages") thus took the form of a lump sum.

The value of the gage and tasks were the most common subjects of litigation, as labourers and servants quite often threatened to go to court, though they rarely did so. However, when they did, they had a good chance of winning their case. Rural employers then accused justices of the peace of being "on the side of labourers and servants", ${ }^{\text {II }}$ just as industrial employers accused prud'bommes of "sitting with workers". ${ }^{\text {II } 2}$ Any breach of contract for "serious reasons" - which might range from illness to insubordination, which included "unkindness" - was punished by civil penalties. That was one of the major outcomes of the Revolution and a sharp difference between France and everywhere else in the nineteenth century. Even if most wage-earners were servants, they were no longer subject to criminal sanction in labour disputes. That does not mean that criminal rules disappeared from labour regulation.

AN C844-958; parliamentary enquiry of I 870 is in AN C I I57-6r. For nineteenth-century collections of local customs, see for example: Usages locaux ayant force de loi dans le département de la Meuse (Bar-le-Duc, I900); I. Bertrand, Usages locaux du département de la Haute-Loire (Le Puy, I865); A. Dumay, Usages locaux du département de la Côte d'Or (I884); R. Mosse, Les usages locaux de l'arrondissement d'Orange (Orange, I9I4); J.M.P. Limon, Recueil des usages locaux en vigueur dans le finistère (Quimper, I852); and H. Watrin, Département de l'Eure-et-Loire: usages des quatre arrondissements et notions de droit usuel (Chartres, I910).

I IO. Jean-Luc Mayaud, "Salariés agricoles et petite propriété dans la France du XIXe siècle", in Ronald Hubscher and Jean-Claude Farcy (eds), La moisson des autres (Paris, 1996). pp. 29-56. I II. Yvonne Crebouw, "Droit et obligations des journaliers et des domestiques, droits et obligations des maîtres", in Hubscher and Farcy, La moisson des autres, pp. I8 I-200.

I I 2. Cottereau, "Droit et bon droit". 
Labour relations and labour mobility were regulated by specific controls connected to the workbook (livret ouvrier). That record was kept by the employer and served a twofold purpose: from the standpoint of the public authorities, it was used to guarantee public order and keep track of workforce movements; from the employer's point of view, it served to control the workforce and protect the employer from poor conduct on the part of wage-earners and other employers. ${ }^{113}$ Indeed, in order to be taken on, a wage-earner had to present his workbook along with proof of discharge from his previous employer. That discharge was provided only if the wage-earner was not indebted, through an advance on wages, or in the case of bespoke workers, through an advance on raw materials. Such workers received raw materials from their employer; the discharge prevented the untimely departure of those workers or fraud in relation to raw materials. ${ }^{\text {II } 4}$

At the same time, the livret also constituted an instrument to control relationships between employers, particularly the possibility of one employer "poaching" workers from another. Without the approval of the first employer, as evidenced from the livret, no transfer could take place without that potentially leading to a legal dispute. ${ }^{\text {II }}$ Disputes often fell within the scope of unfair competition. The notion of poaching was thus linked to apprenticeship. Employers did not want to waste their investment in training their workers, so discharge letters served to curb worker mobility and encourage agreements between employers. The letters testified to the worker's debt to his employer, whether in the form of an advance on wages, an apprenticeship contract, or the rental of tools or machines, and had to be signed and countersigned by all the employers involved. ${ }^{116}$

I I3. Répertoire Dalloz, XXVII, p. 397, n. I (1852); rapport Bertrand sur le projet de loi du 26 juin I 854 , Dalloz (1854), p. i 9 .

I I4. Henri Bernard, Le Livret ouvrier (Paris, I903); Jean-François Germe, "Le livret ouvrier: mobilité et identification des salaries", in Robert Salais and Laurent Thévenot (eds), Le travail. Marchés, règles, conventions (Paris, I986), pp. 357-370; Jean-Pierre Le Crom, "Le livret ouvrier au XIXe siècle entre assujettissement et reconnaissance de soi”, in Yvon Le Gall, Dominique Gaurier, and Pierre-Yannick Legal (eds), Du droit du travail aux droits de l'bumanité. Études offerts à Philippe-Jean Hesse (Rennes, 2003), pp. 91-100; J. Le Goff, Du silence à la parole (Paris, 2004), p. 59; A. Dewerpe, "En avoir ou pas? A propos du livrer ouvrier", paper presented at the conference, "Time and Labor Constraints in France and Japan", held at the Maison Franco-Japonaise, Tokyo, June 2007.

I I 5. Cour de Douai, Sirey, Recueil générale des lois et des arrets (I874), II, I84; Dalloz (I 874), II, II 4 .

I 16. C. Sabel and J. Zeitlin (eds), World of Possibilities: Flexibility and Mass Production in Western Industrialization (Cambridge, 1997), and especially the essay by A. Cottereau, "The Fate of Collective Manufacturers in the Industrial World: The Silk Industries of Lyons and London, I800-1850", pp. 75-I 52; G. Gayot, Les draps de Sedan (1640-I870) (Paris, I998); A. Cottereau, "Industrial Tribunals and the Establishment of a Kind of Common Law of 
The situation changed slowly over the course of the century. Beginning in the I840s, new labour legislation was enacted, first with regard to child labour, then working hours and working conditions in general. ${ }^{\mathrm{II}}$ On the other hand, contractual relationships in the strict sense evolved much more slowly. The "total subordination" of servant to master and the unequal penalties they faced in cases of breach of contract had been under attack since the middle of the century, but attempts to change the civil code failed. The argument raised by employers' associations was the same as that used in relation to other forms of subordination and coerced labour, including indenture, namely the "voluntary" character of the engagement. However, that argument would become outdated, and important changes would occur. The growing importance of trade unions, particularly after the repeal of the law against "coalition" in I 864 and the law on associations of I884, the strong competition of the city in the rural urban market, ${ }^{118}$ and the reorientation of jurisprudence all contributed to the increasing identification of labour employment with renting of service. ${ }^{\text {II }}$

Such a shift would not have been possible without the activity of the other branch of labour competition - "coalitions". Coalitions were forbidden in I79I, with the official aim of preserving competition in the labour market, ${ }^{\mathrm{I} 20}$ an attitude that prevailed in both public debates, economic thought, and jurisprudence right up to the mid-nineteenth century. ${ }^{\text {I2I }}$ The notion of coalition as a crime would be eliminated only in

Labour in Nineteenth-Century France”, in Steinmetz, Private Law and Social Inequality in the Industrial Age, pp. 203-226.

I 17. C. Lemercier, “Apprentissage”, in A. Stanziani (ed.), Dictionnaire historique de l'économie-droit, XVIIIe-XXe siècles (Paris, 2007), pp. 23-34; and Y. Lequin, "Apprenticeship in Nineteenth-Century France: A Continuing Tradition or a Break with the Past?", in Steven Laurence Kaplan and Cynthia J. Koepp (eds), Work in France: Representations, Meaning, Organization, and Practice (Ithaca, NY, 1986), pp. 457-474; Steven L. Kaplan and Gilles PostelVinay, "L'apprentissage: un destin?", Le Gnomon, I26 (2000), pp. 23-24; Revne d'histoire moderne et contemporaine, dossier "Apprentissages, $\mathrm{XVI}^{\mathrm{e}}-\mathrm{XX}^{\mathrm{e}}$ siècles", 40:3 (I993); Olivier Tholozan, "Le débat parlementaire de I8 5 I sur le contrat d'apprentissage ou la liberté contractante acclimatée", Cabiers de l'IRT, 9 (2001), pp. 207-222; J. Freyssinet, "Hétérogénéité du travail et organisation des travailleurs", fascicule 3, La révolution industrielle, IRES Working Papers, January 2005.

I 18. Yvonne Crebouw, Salaires et salariés agricoles en France des débuts de la Révolution aux approches $d u X X e$ siècle (Paris, 1986).

I 19. Cottereau, "Droit et bon droit".

I 20. $\mathrm{AN} \mathrm{BB} \mathrm{24,} \mathrm{I00-I} \mathrm{I} \mathrm{5:} \mathrm{coalition} \mathrm{ouvrières} \mathrm{à} \mathrm{Darnetal,} \mathrm{Seine-Inférieure,} \mathrm{en} \mathrm{septembre} \mathrm{I} \mathrm{830;}$ BB 24, I95-2 I8: coalitions d'ouvriers à Paris, le $\mathrm{I}^{\mathrm{e}}$ septembre $\mathrm{I} 840$, contre l'introduction de machines anglaises; BB 24 327-347: coalitions et troubles à Lyon, bris de machines et métiers, fin février 1848 .

I 2 I. "Le commerce et le monopole. Nouvelle lettre de M. Jobard en réponse à des observations de M. Joseph Garnier”, Journal des économistes, I I (I J January I 855), pp. 100-105; "Les vingt questions de M. Jobard sur la concurrence, suivies de vingt réponses par M. Joseph Garnier", Journal des économistes, I 2 (1855), pp. 247-256; "Chronique économique", Journal des économistes, 
I864. The main supporters of repealing the law against coalition maintained that the criminalization of coalition was a burden not only on workers, but on employers too, who suffered from a lack of coordination. The official attitude was widely supposed to encourage political extremism. ${ }^{122}$ Once the crime of coalition had been abolished, the question arose of the link between coalitions and the manner in which contracts were made. Was it lawful for a union to press an employer into dismissing a worker who had been freely employed? The Cour de Cassation decided that the defendant (the union) was liable for damages to the plaintiff, the court apparently seeing the union's threat as a legal means directed towards an illegal end. ${ }^{\mathrm{I} 3}$

That is to say that in France, the emergence of the general idea of unfair competition was possible only at the moment when competition on the labour market gained a new dimension, when criminal punishments for coalition were abolished and the new labour contract replaced the old louage d'ouvrage and louage de service. That turning point took place in a context marked by the emergence of the welfare state. The protection of labour as an instrument to defend capitalism against the rise of socialism was confirmed at the turn of the century and culminated first in the official recognition of trade unions (I884), then in the suppression of the livret ouvrier (I 890), and finally in the law on industrial accidents (I 898), which required employers to pay part of the premiums for wage-earners' insurance. Those elements converged in the labour code of $1910,{ }^{124}$ which defined the labour contract as a contract of subordination, as we know it today. The specification of causes for dismissal or grounds for breach of contract, the central political role played by trade unions, and the very definition of subordination were therefore turn-of-the-century inventions.

To sum up, the "French exception" was more limited than has usually been asserted. Eighteenth-century rules included lifetime engagement and service; criminal penalties for breach of contract were reduced, but during most of the nineteenth century they persisted for workers' coalitions and indentured labourers.

2nd series, I25 (May 1864), pp. 32 I-323; “Des moyens de remédier aux abus des coalitions", Journal des économistes, 75 (March I 872), pp. 477-486.

I 22. E. Ollivier, Commentaire de la loi du Is mai I 864 sur les coalitions (Paris, I864), pp. 52-53. I23. Cassation civile, 22 June I892, Sirey, Recueil générale des lois et des arrets (I893), I, 42. This case was discussed on appeal by Chamberry's Cour d'Appel, which upheld the ruling of the first tribunal (I 4 May i 893, Sirey, Recueil générale des lois et des arrets (1893), II, I 39; Dalloz (I893), II, I9I). See also the ruling by the Cour de Cassation on 9 June I896, Dalloz ( I 896), I, 582. For a discussion of this case, see Vernon Palmer, "A Comparative Study (From a Common Law Perspective) of the French Action for Wrongful Interference with Contract", American Journal of Comparative Law, 40 (1992), pp. 297-342.

I24. C. Didry, Naissance de la convention collective (Paris, 2002). 


\section{CONCLUSION}

Between the sixteenth and the end of the nineteenth century, the barrier between freedom and bondage was not only moveable and negotiable, it also thought of differently from how we are used to thinking of it today. In fact, in modern times and until the end of the nineteenth century, labour was submitted to serious legal constraints, usually justified by reference to the "debt" or the "deed" the worker, or the peasant, had contracted with both master and community. Such things encompassed apprenticeship, wage advances, land, raw materials and seeds, and so on. "Runaways" included not only slaves and indentured workers but "serfs", servants, and apprentices too, and all of them could find themselves subject to criminal as well as civil penalties. They were neither "free economic actors" choosing their status as entrepreneurs or workers in the "neoclassical" sense, nor were they "proletarians" in the Marxist sense.

In reality, in most "Western" countries labour was similar to service and wage conditions resembled those of domestic servants, with numerous constraints imposed on work mobility. The material and living conditions of "free" workers and servants were not necessarily better than those of "serfs," although the difference lay in the scope lowly people had to seize the law and use it to improve their situation. In fact, France was the first country to repeal criminal sanctions against workers and to make "labour" fundamentally different from "service". However, that "exception" held good much less for rural labourers and indentured workers in the colonies, and was partially nullified by an interdiction of workers' coalitions. In turn, Britain experienced a long-term tradition of master-servant relations crossing the boundaries of the medieval, modern, and contemporary periods. Once again, free and unfree forms of labour were much more in concert than in opposition; the close link between the status of servants and that of indentured labourers confirms the point.

At the opposite end of the scale, in Russia and Poland, landlords exploited existing rules in order to create an informal market for "serfs". Even if legal constraints on labour were harsher there than in Britain or in France, peasants and workers were not entirely deprived of legal rights, and they did manage to exploit their legal protection in the courts. In Russia, changes of legal status occurred on a huge scale before the official emancipation of $\mathrm{I} 86 \mathrm{I}$.

Throughout the period studied here, free and unfree forms of labour were therefore much less in opposition than in action side by side, and many forms of unfree labour were actually still considered "free" engagements. At a global level, in Europe and its colonies, in Russia, and in Asia, the institutional and economic dynamics from the seventeenth to the end of the nineteenth century, which saw agrarian, consumption, commercial and the first industrial revolutions, to say nothing of the 
proto-industrial dynamics they witnessed, were therefore most firmly based upon this peculiar classification of labour and labour institutions. It was only at the turn of the twentieth century that the idea of labour as service definitely collapsed, criminal penalties disappeared, and coercion became incompatible with the new notion of the labour contract, at least in Europe and the United States. By contrast, Russia, Asia, and the European colonies would experience new forms of heavy and widespread bondage. 